УДК: $351.74 / 76$

DOI: https://doi.org/10.32366/2709-9261-2021-1-1-123-131
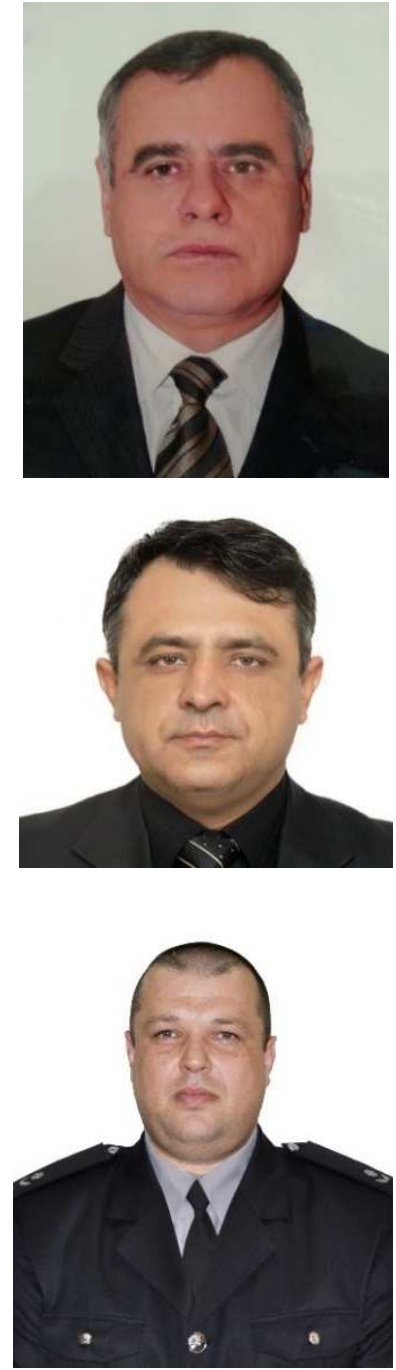

Ульянов Олексій Іванович, кандидат юридичних наук, доцент, заслужений діяч науки і техніки України (Одеський державний університет внутрішніх справ, м. Одеса) ORCID: https://orcid.org/0000-0002-3397-0965

Ніколаєв Олександр Трифонович, кандидат політичних наук, доцент (Одеський державний університет внутрішніх справ, м. Одеса) ORCID: https://orcid.org/0000-0003-4752-0110

Бахчеван Євген Федорович, старший викладач

(Одеський державний університет внутрішніх справ, м. Одеса)

ORCID: https://orcid.org/0000-0002-1459-9574

\section{ЗАПРОВАДЖЕННЯ СКАНДИНАВСЬКОЇ МОДЕЛІ} ЗАБЕЗПЕЧЕННЯ ПУБЛІЧНОЇ БЕЗПЕКИ ТА ПОРЯДКУ ПІД ЧАС ПРОВЕДЕННЯ МАСОВИХ ЗАХОДІВ У ДІЯЛЬНОСТІ НАЦІОНАЛЬНОЇ ПОЛІції УКРАїнИ

у статті розкрито особливості та переваги скандинавської моделі охорони громадського порядку та безпеки під час масових заходів. Одним із ключових елементів нової конщепції охорони громадського порядку $\epsilon$ запровадження «поліиії діалогу». Чотири засади цього підходу: по-перше, отримати якомога більше знань про склад будь-якого натовпу; подруге, навчитися розрізняти різні частини натовпу та визначати, де $\epsilon$ ризики; по-третє, постійний діалог та спілкування з організаторами заходів та членами натовпу i, нарешті, сприяння. Висвітлено поняття громадського порядку. Проаналізовано правову основу проведення масових заходів в Україні. Установлено, що однією з проблем реалізації скандинавської моделі є відсутність спеціального закону про проведення масових заходів. Для реалізації основного принципу "поліції діалогу», який передбачає зв'язок поліції та організаторів масових заходів, важливо встановити чіткий порядок повідомлення про такі події. Обгрунтовано необхідність прийняття спеціального закону про масові заходи в Україні, а також визначення порядку повідомлення про масові заходи, які повинні подаватися до органів Національної поліції.

Ключові слова: поліція; публічний порядок; скандинавська модель; масові заходи; поліція діалогу.

Постановка проблеми. Положення Конституції України про те, що права і свободи людини та їх гарантії визначають зміст і спрямованість діяльності держави [1], вимагає забезпечення їх належної реалізації, охорони та захисту. Як свідчить практика, значна частина прав і свобод громадян реалізуються у сфері публічного порядку, що обумовлює особливу відповідальність держави за створення такого рівня публічного порядку, стан якого забезпечував би оптимальні умови для їх реалізації.

Серед суб'єктів, які забезпечують належний рівень публічної безпеки та порядку, провідне місце посідає Національна поліція України. 3 проведенням 
реформи, прийнятяям Закону України «Про Національну поліцію» започатковано нові засади діяльності поліції, яка спрямована на служіння суспільству шляхом забезпечення охорони прав і свобод людини, протидії злочинності, підтримання публічної безпеки і порядку.

Зміцнення гарантій прав громадян у сфері публічного порядку залежить не лише від оновлення законодавства, а й від удосконалення: а) організаційної структури поліції; б) підвищення кваліфікації співробітників цих органів; в) технічного, матеріального та психологічного забезпечення; г) упровадження позитивного міжнародного досвіду в національну практику.

Кожен з означених напрямів, від якого залежить підвищення ефективності діяльності органів Національної поліції щодо охорони і захисту прав громадян у сфері публічного порядку, має важливе значення, однак їх реалізація для досягнення високих результатів має відбуватися комплексно.

Важливе значення для впровадження нових практик з охорони публічного порядку, взаємодії Національної поліції з державними і громадськими інституціями в цій сфері має вивчення міжнародного досвіду діяльності правоохоронних органів та можливості його запровадження в національній практиці. Вивчення і впровадження міжнародного досвіду може відбуватися як через реалізацію програм академічної освітньої та наукової мобільності представниками закладів вищої освіти України та зарубіжних країн, так і завдяки співпраці Міністерства внутрішніх справ України, Національної поліції України з відповідними правоохоронними органами зарубіжних країн.

Застосування передових європейських практик у діяльності Національної поліції має вагоме значення для забезпечення прав та інтересів громадян та $€$ важливим напрямом реалізації Угоди про асоціацію України та Європейського Союзу (далі-€C).

Важливе значення для впровадження скандинавської моделі має чітке визначення категорії «публічний порядок» як ключової сфери, у якій передбачається охорона та захист прав та інтересів громадян Національною поліцією.

Аналіз останніх досліджень і публікацій. Структуру та основні елементи дефініції «публічний порядок» досліджено в наукових працях С.А.Коміссарова, який у докторській дисертації надав авторське визначення публічного порядку як «врегульовану правовими та іншими соціальними нормами систему суспільних відносин, що забезпечує захист прав і свобод громадян, їхнє житяя і здоров'я, повагу до честі та людської гідності, дотримання норм суспільної моралі не лише в місцях спільного користування - публічних місцях, а й приватних місцях, у яких перебувають інші члени суспільства, права і свободи яких захищають норми законодавства, органи державної влади і правоохоронні органи» [2, с.11].

О. Ф. Кобзар публічний порядок пропонує розглядати в широкому, вузькому та спеціальному значенні. У широкому розумінні публічний порядок автор розглядає як певну частину суспільних відносин, які складають режим життєдіяльності у відповідних регіонах, власності та умов, що склалися для нормальної діяльності установ, підприємств, організацій, посадових осіб і громадян, й у свою чергу урегульовані правовими та іншими соціальними нормами.

У вузькому значенні публічний порядок розглядається як результат, що полягає в дотриманні та неухильному виконанні кожним із суб'єктів своїх прав та обов'язків, які, безперечно, пов'язані із суспільними відносинами, зміст яких 
забезпечує недоторканність життя, здоров'я та гідності громадян, власності, умов нормальної діяльності установ, підприємств, посадових осіб і громадян.

У спеціальному (поліцейському) значенні публічний порядок науковець визначає як правомірну поведінку в публічних місцях, охорона якої здійснюється наглядовими органами виконавчої влади, тобто поліцейськими підрозділами, які слідкують та протидіють насиллю одних громадян над іншими [3, с. 36]. Окремі питання впровадження скандинавської моделі відображено у працях Д. В. Цуркана, який, розкриваючи проблемні питання роботи груп комунікації під час проведення масових заходів, зазначає, що з вересня 2016 року в Україні розпочала свою діяльність Консультативна Місія Європейського Союзу (далі - КМЄС) з реформування сектора цивільної безпеки. Проєкт спрямовано на підтримку нової української моделі охорони громадського порядку, яка базуватиметься на «скандинавському підході», що визнаний одним із найефективніших у Європі [4, с. 302-304].

Попри фрагментарне висвітлення переваг та перспектив упровадження міжнародної практики з охорони прав та інтересів громадян у сфері публічного порядку, залишається ще чимало питань, які потребують комплексного дослідження.

О.Г. Юшкевич, досліджуючи питання особливостей реформування поліції в Україні на шляху європейської інтеграції, звертає увагу на такі важливі завдання скандинавської моделі, як попередження насильства під час масових заходів, акцентуючи при цьому увагу на таких принципах, як сприяння проведенню мирних зібрань та підтримки демократичних прав громадян. Дослідниця робить висновок, що поліція має бути забезпечена детальним, зрозумілим законодавством, бо без нього поліцейські часто керуються власною правосвідомістю, яка іноді не сприяє реалізації прав людини [5, с. 33-37].

Мета дослідження - розкрити переваги скандинавської моделі забезпечення публічної безпеки та порядку під час проведення масових заходів та передумови їі запровадження в національній практиці.

Виклад основного матеріалу. 3 метою впровадження нових практик та зміни парадигми поведінки працівників Національної поліції України під час забезпечення прав та інтересів громадян у сфері публічного порядку, які 6 ґрунтувалися на позитивному зарубіжному досвіді, за основу було взято скандинавську модель забезпечення публічної безпеки та порядку під час проведення масових заходів.

Наказом МВС України від 23 серпня 2018 року [6] затверджено Концепцію запровадження в діяльності органів та підрозділів Національної поліції України скандинавської моделі забезпечення публічної безпеки та порядку під час проведення масових заходів. Основною метою Концепції $\epsilon$ заміна застарілої реактивної моделі поведінки під час забезпечення публічної безпеки та порядку в разі проведення масових заходів новою - проактивно орієнтованою.

Скандинавська модель передбачає попередження насильства під час масових заходів шляхом постійного спілкування з натовпом, ретельного планування та аналізу ризиків.

Особливості скандинавського підходу забезпечення громадського порядку окреслила фахівець КМЄС Ізабел Торен, яка зазначила, що скандинавська модель передбачає попередження насильства під час масових заходів шляхом постійного спілкування з натовпом, ретельного планування та аналізу ризиків; вона також підкреслила, що одним з основних принципів моделі $є$ деескалація: обізнаність правоохоронців із ситуацією, їхня комунікація з учасниками заходу, диференціація 
учасників та сприяння проведенню мирних зібрань без перешкоджання проявам демократичних прав і свобод громадян [7].

Провідний радник КМЕС з питань охорони громадського порядку Патрік Йохансен зазначив, що ключовим елементом усієї концепції є деескалація, яка включає чотири основні складові:

- володіння інформацією про те, хто бере участь у масовому зібранні;

- уміння розрізняти групи, що входять до складу натовпу, та визначати ризики;

- постійний діалог з організаторами заходу і власне учасниками массового зібрання;

- сприяння.

Сприяння, зі слів Патріка Йохансена, полягає у спрямуванні роботи поліції на захист прав людини, наприклад права на свободу зібрань, уже на стадії отримання від організаторів заяви на проведення якогось заходу чи масового зібрання, шляхом надання допомоги їм успішно реалізувати ці наміри.

Важливим елементом скандинавської моделі, який підвищує ефективність роботи поліції, є застосування «диференційованого підходу», тобто збільшення або зменшення кількості поліцейських, які забезпечують громадський порядок під час проведення заходів, відповідно до ситуації [8] .

Слід зазначити, що з метою реалізації Концепції запровадження в діяльності органів та підрозділів Національної поліції України скандинавської моделі забезпечення публічної безпеки та порядку під час проведення масових заходів у роботі поліції відбулися суттєві зміни.

По-перше, створено «Поліцію діалогу» - «перемовники» під час проведення масових заходів спілкуються з організаторами та учасниками з моменту подачі заявки про її проведення до завершення заходу.

По-друге, Національною поліцією затверджено Стандартні операційні процедури щодо забезпечення публічної безпеки і порядку.

По-третє, змінено підходи до організації роботи:

- постійна комунікація з учасниками заходів шляхом активного використання можливостей «Поліції діалогу»;

- висока мобільність залучених сил, яка досягається використанням спеціалізованих транспортних засобів;

- мінімізація демонстрації сили (поліцейський у захисному спорядженні як виключення та вимушений захід) [9].

Отже, можна констатувати, що проактивний підхід усебічно втілюється саме в скандинавській моделі забезпечення публічної безпеки та порядку під час проведення масових заходів, а його запровадження в діяльність органів і підрозділів Національної поліції України буде дієвим засобом реалізації демократичних принципів у поліцейській діяльності, забезпечення основних прав і свобод громадян, особливо в реалізації їхніх права на свободу зібрань, дозволить підвищити рівень довіри громадян до поліції.

Упровадження нової моделі потребує не лише вивчення міжнародних практик, обмін досвідом та підготовку фахівців, а й належне правове регулювання відносин у відповідній сфері на національному рівні.

Враховуючи, що сутність скандинавської моделі полягає, зокрема, у всебічній комунікації поліції з учасниками масових заходів, починаючи з етапу їх планування, насамперед слід звернути увагу на проблему, пов'язану з відсутністю належного 
правового регулювання відносин у сфері організації та проведення масованих заходів.

Право на мирне зібрання, зважаючи на його важливість як для суспільства, так і окремого громадянина, закріплено на рівні міжнародно-правових актів. Серед таких актів слід зазначити Загальну декларацію прав людини (1948р.), у якій проголошено, що кожна людина має право на свободу мирних зборів і асоціацій [10].

Слід зауважити, що в міжнародно-правових актах, які були прийняті після Загальної декларації прав людини, а саме в Міжнародному пакті про громадянські і політичні права (1966р.) [11], Конвенції про захист прав людини і основоположних свобод (1950р.) [12] та в Копенгагенському документі Організації з безпеки та співробітництва в Європі (далі - ОБСЄ ) [13], окрім того, що задекларовано право кожної людини на мирні зібрання і демонстрації, закріплено норму, що здійснення цих прав не підлягає жодним обмеженням, за винятком тих, що встановлені законом і $\epsilon$ необхідними в демократичному суспільстві в інтересах національної або громадської безпеки, для запобігання заворушенням чи злочинам, для охорони здоров'я чи моралі або для захисту прав і свобод інших осіб; що будь-які обмеження, які можуть бути встановлені щодо здійснення цих прав, визначаються законом і відповідають міжнародним стандартам.

Названі міжнародні акти встановлюють загальні принципи права на мирні зібрання, а кожна зацікавлена держава це право підтверджує на конституційному рівні та інших нормативно-правових актах, які конкретизують діяльність органів державної влади щодо забезпечення реалізації прав громадян на мирні зібрання.

У нашій державі право громадян на мирні зібрання закріплено в Конституції України. Так, у статті 39 установлено право громадян збиратися мирно, без зброї і проводити збори, мітинги, походи і демонстрації, про проведення яких завчасно сповіщаються органи виконавчої влади чи органи місцевого самоврядування.

Обмеження щодо реалізації цього права може встановлюватися судом відповідно до закону і лише в інтересах національної безпеки та громадського порядку - з метою запобігання заворушенням чи злочинам, для охорони здоров'я населення або захисту прав і свобод інших людей.

На жаль, в Україні відсутній модельний закон щодо проведення масових заходів, який закріплював би механізм правовідносин у зазначені сфері. За відсутності такого закону виникають певні проблеми щодо здійснення громадянами своїх конституційних прав на мирні зібрання.

Проблемним питанням щодо здійснення права на мирні зібрання є реалізація положення частини першої статті 39 Конституції України про завчасне сповіщення органів виконавчої влади чи органів місцевого самоврядування про проведення зборів, мітингів, походів і демонстрацій.

За офіційним тлумаченням положення частини першої статті 39 Конституції України про завчасне сповіщення органів виконавчої влади чи органів місцевого самоврядування про проведення зборів, мітингів, походів і демонстрацій Міністерство внутрішніх справ України звернулося з конституційним поданням до Конституційного Суду України. У поданні наголошувалося, що конкретного строку, протягом якого необхідно сповістити органи виконавчої влади чи органи місцевого самоврядування про проведення зазначених акцій, чинним законодавством України не встановлено, що призводить до того, що інформація направляється до органів виконавчої влади чи органів місцевого самоврядування за добу до початку масових акцій, а інколи - за кілька годин. 
У своєму рішенні щодо завчасного сповіщення органів виконавчої влади чи органів місцевого самоврядування про проведення зборів, мітингів, походів і демонстрацій Конституційний Суд України зазначив, що організатори таких мирних зібрань мають сповістити вказані органи про проведення цих заходів заздалегідь, тобто у прийнятні строки, що передують даті їх проведення, а визначення конкретних строків завчасного сповіщення з урахуванням особливостей форм мирних зібрань, їх масовості, місця, часу проведення тощо $\epsilon$ предметом законодавчого регулювання [14]. Таке рішення обумовлено п. 1 4. 1 ст. 92 Конституції України про те, що виключно законами визначаються права і свободи людини і громадянина, гарантії цих прав і свобод і що лише судом відповідно до закону може встановлюватися обмеження щодо реалізації права громадян на проведення масових зібрань (ч. 2 ст. 39 Конституції України). Отже, на підставі положень Конституції України і рішення Конституційного Суду України мало б бути прийнято закон, який урегулював би питання щодо проведення мирних зібрань.

Такі закони прийнято в країнах СНД: Азербайджан (1998р.); Вірменія (2011р.); Білорусь (1997р.); Казахстан (2020р.); Киргизстан (2012 р.); Молдова (2008 р.); Таджикистан (2014р.); Туркменістан (2012р.).

Аналогічні закони прийнято в країнах G8: Велика Британія (1986р.); Германія (1978 р.); Італія (1975 р.); Франція (1935 р.).

Спільним для законів країн СНД та країн G8 щодо проведення мирних зібрань $€$ те, що всі вони прописують чіткий механізм реалізації громадянами прав у зазначеній сфері. Важливим, у контексті нашого дослідження, $\epsilon$ те, що в них прописано терміни подання заяви організатором на проведення мирного заходу та компетенцію державних органів влади щодо розгляду таких заяв.

Так, Законом Швеції про громадський порядок визначено порядок організації та проведення публічних зборів та заходів, порядок повідомлення управління поліції про заплановані заходи, вимоги щодо дотримання громадського порядку та забезпечення безпеки, підстави для відмови у проведенні публічних зборів чи масових заходів. Заявку на проведення заходів слід подавати в письмовому вигляді завчасно. За можливості, заявка повинна бути отримана не пізніше ніж за тиждень до зустрічі або заходу. За можливості, реєстрація повинна бути отримана не пізніше ніж за 5 днів до зустрічі або заходу [15]. Подати заявку можна в письмовому або електронному вигляді. Форма заявки, розмір збору розміщено на офіційному сайті поліції Швеції. У розділі подання заявок на проведення публічних заходів зазначено, що заявку може бути відхилено у випадку, якщо вона надійде занадто пізно [16].

Подання заявки про проведення заходу безпосередньо до органів поліції $€$ також важливою умовою застосування скандинавської моделі. Оскільки це гарантує отримання інформації безпосередньо органом, відповідальним за охорону публічного порядку, можливість оперативного вжитя необхідних заходів та забезпечення безпосередньої комунікації з організаторами масових заходів.

Проаналізувавши вітчизняну та зарубіжну нормативно-правову базу щодо проведення мирних зібрань, дійшли висновку про практичну необхідність та важливість прийняття в Україні спеціального закону, який урегулював би право громадян на мирні зібрання. Для реалізації заходів щодо запровадження в діяльності органів та підрозділів Національної поліції України скандинавської моделі забезпечення публічної безпеки та порядку під час проведення масових заходів доцільно передбачити порядок подання заявок про проведення масових заходів до органів Національної поліції. 
Висновки. Заміна застарілої реактивної моделі поведінки працівників поліції під час забезпечення публічної безпеки та порядку в разі проведення масових заходів новою - проактивно орієнтованою - відображає сутність скандинавської моделі забезпечення публічного порядку в зазначеній сфері, яка направлена на попередження насильства шляхом постійного спілкування з натовпом. Для реалізації громадянами конституційного права на мирні зібрання необхідно розробити та прийняти закон, у якому було б урегульовано правовідносини в зазначеній сфері, прописано чіткий механізм організації та проведення масових зібрань.

Список використаних джерел

1. Конституція України : офіц. текст. Київ: КМ, 2013. 96 с.

2. Коміссаров С.А. Адміністративно-правове забезпечення публічного порядку в сучасних умовах: вітчизняний та зарубіжний досвід : дис. ... А-ра юрид. наук : 12.00.07. Київ, 2020. 477 С.

3. Кобзар О. Ф. Адміністративно-правове регулювання поліцейської діяльності в Україні : автореф. дис. ... А-ра юрид. наук : 12.00.07. Дніпропетровськ, 2016. 36 с.

4. Цуркан А. В. Робота груп комунікації під час проведення масових заходів. Актуальні питання забезпечення публічної безпеки : тези доп. всеукр. наук.-практ. конф. (м. Маріуполь, 12 трав. 2018 р.). Маріуполь, 2018. С. 300-304.

5. Юшкевич О. Г. Особливості реформування поліції в Україні на шляху Європейської інтеграції. Науковий вісник Дніпропетровського державного університету внутрішніх справ. 2019. № 3. С. 33-37.

6. Концепція запровадження в діяльності органів та підрозділів Національної поліції України скандинавської моделі забезпечення публічної безпеки та порядку під час проведення масових заходів : наказ MBC України від 23.08.2018 p. № 706. URL: http://search.ligazakon.ua/l_doc2.nsf/link1/MVS873.html (дата звернення: 11.01.2021).

7. Українські правоохоронці вивчають скандинавську модель забезпечення публічної безпеки. єдиний органів системи MBC України. Департамент комунікації MBC України. URL: https://mvs.gov.ua/ua/news/10826 Ukrainski pravoohoronci vivchayut skandinavsku model zab ezpechennya_publichnoi_bezpeki_FOTO.htm/ (дата звернення: 11.01.2021).

8. Про скандинавський підхід до охорони громадського порядку і налагодження діалогу працівниками поліції, про «євробачення» та інше - інтерв'ю з Патріком Йохансеном, провідним радником KMEC з питань охорони громадського порядку. URL: https://www.euamukraine.eu/ua/news/opinion/the-scandinavian-approach-to-public-order-policing-dialogueeurovision-and-more-interview-with-patrik-johansen-euam-lead-adviser-in-public-order/

(дата звернення: 14.01.2021).

9. Звіт Голови Національної поліції України про результати роботи відомства у 2019 році. URL: https://www.kmu.gov.ua/storage/app/sites/1/17-civik-2018/zvit_2019/zvit-npu-2019.pdf (дата звернення: 14.01.2021).

10. Загальна декларація прав людини. https://zakon.rada.gov.ua/laws/show/995_015\#Text) (дата звернення: 14.01.2021).

11. Міжнародний пакт про громадянські і політичні права прийнято 16 грудня 1966 року Генеральною Асамблеєю ООН. Док. ООН A/RES/2200 A (XXI). URL: https://zakon.rada.gov.ua/laws/show/995_043\#Text (дата звернення: 14.01.2021).

12. Конвенція про захист прав людини і основоположний свобод. 4 листопада 1950 p. URL: https://zakon.rada.gov.ua/laws/show/995_004\#Техt (дата звернення: 14.01.2021).

13. Документ Копенгагенского совещания Конференции по человеческому измерению СБСЕ Копенгаген, 29 июня 1990 г. URL: https://zakon.rada.gov.ua/laws/show/994_082\#Text (дата звернення: 15.01.2021).

14. Рішення Конституційного Суду України у справі за конституційним поданням Міністерства внутрішніх справ України. м. Київ, 19 квітня 2001 року, справа № 1-30/2001. URL: https://zakon.rada.gov.ua/laws/show/v004p710-01\#Text (дата звернення: 14.01.2021).

15. Public Order Act URL: https://www.riksdagen.se/sv/dokument-lagar/dokument/svenskforfattningssamling/ordningslag-19931617_sfs-1993-1617 (дата звернення: 15.01.2021).

16. Apply for a permit for a public gathering URL: https://polisen.se/en/services-and-permits/permitsand-licences/permit-for-a-public-gathering/ (дата звернення: 15.01.2021). 
References

1. Konstytutsiia Ukrainy : ofits. tekst [The Constitution as the main law of Ukraine enshrines the fundamental rights and freedoms of man and citizen]. Kyiv: KM, 2013. 96 s. [in Ukrainian].

2. Komissarov, S. A. (2020). Administratyvno-pravove zabezpechennia publichnoho poriadku $v$ suchasnykh umovakh: vitchyznianyi ta zarubizhnyi dosvid: dys. ... d-ra yuryd. nauk : 12.00.07 [The Thesis is a complex research of domestic and experience of administrative and legal support of public order in the current context]. Kyiv. $477 \mathrm{~s}$. [in Ukrainian].

3. Kobzar, O. F. (2016). Administratyvno-pravove rehuliuvannia politseiskoi diialnosti $v$ Ukraini : avtoref. dys. ... d-ra yuryd. nauk : 12.00.07 [The Thesis deals with the analysis of administrative and legal regulation of policing in Ukraine]. Dnipropetrovsk. 36 s. [in Ukrainian].

4. Tsurkan, D. V. (2018). Robota hrup komunikatsii pid chas provedennia masovykh zakhodiv. Aktualni pytannia zabezpechennia publichnoi bezpeky : tezy dop. vseukr. nauk.-prakt. konf. (m. Mariupol, 12 trav. 2018 r.) [The work of communication groups during mass events]. Mariupol. S. 300-304 [in Ukrainian].

5. Yushkevych, O. H. (2019). Osoblyvosti reformuvannia politsii v Ukraini na shliakhu Yevropeiskoi intehratsii [Features of police reform in Ukraine on the path to European integration]. Naukovyi visnyk Dnipropetrovskoho derzhavnoho universytetu vnutrishnikh sprav. № 3. S. 33-37 [in Ukrainian].

6. Kontseptsiia zaprovadzhennia $v$ diialnosti orhaniv ta pidrozdiliv Natsionalnoi politsii Ukrainy skandynavskoi modeli zabezpechennia publichnoi bezpeky ta poriadku pid chas provedennia masovykh zakhodiv : nakaz MVS Ukrainy vid 23 08. 2018 r. № 706 [ The concept of introduction in the activities of bodies and units of the National Police of Ukraine of the Scandinavian model of public safety and order during mass events]. URL: http://search.ligazakon.ua/l_doc2.nsf/link1/MVS873.html (data zvernennia: 11.01.2021) [in Ukrainian].

7. Ukrainski pravookhorontsi vyvchaiut skandynavsku model zabezpechennia publichnoi bezpeky [On the Scandinavian approach to public order and dialogue between police officers]. Yedynyi portal orhaniv systemy MVS Ukrainy. Departament komunikatsii MVS Ukrainy. URL: https://mvs.gov.ua/ua/news/10826_Ukrainski_pravoohoronci_vivchayut_skandinavsku_model_zab ezpechennya_publichnoi bezpeki_FOTO.htm/ (data zvernennia: 11.01.2021) [in Ukrainian].

8. Pro skandynavskyi pidkhid do okhorony hromadskoho poriadku i nalahodzhennia dialohu pratsivnykamy politsii, pro «levrobachennia» ta inshe - interviu z Patrikom Yokhansenom, providnym radnykom KMleS z pytan okhorony hromadskoho poriadku [On the Scandinavian approach to public order and dialogue between police officers]. URL: https://www.euamukraine.eu/ua/news/opinion/the-scandinavian-approach-to-public-order-policing-dialogueeurovision-and-more-interview-with-patrik-johansen-euam-lead-adviser-in-public-order/

(data zvernennia: 14.01.2021) [in Ukrainian].

9. Zvit Holovy Natsionalnoi politsii Ukrainy pro rezultaty roboty vidomstva u 2019 rotsi [Report of the Head of the National Police of Ukraine on the results of the department's work in 2019]. URL: https://www.kmu.gov.ua/storage/app/sites/1/17-civik-2018/zvit_2019/zvit-npu-2019.pdf (data zvernennia: 14.01.2021) [in Ukrainian].

10. Zahalna deklaratsiia prav liudyny [Universal Declaration of Human Rights]. URL: https://zakon.rada.gov.ua/laws/show/995_015\#Text) (data zvernennia: 14.01.2021) [in Ukrainian].

11. Mizhnarodnyi pakt pro hromadianski i politychni prava Pryiniato 16 hrudnia 1966 roku Heneralnoiu Asambleieiu OON.Dok. OON A/RES/2200 A (XXI) [ International Covenant on Civil and Political Rights]. URL: https://zakon.rada.gov.ua/laws/show/995_043\#Text) (data zvernennia: 14.01.2021) [in Ukrainian].

12. Konventsiia pro zakhyst prav liudyny i osnovopolozhnyi svobod. 4 lystopada 1950 r. [Convention for the Protection of Human Rights and Fundamental Freedoms]. URL: https://zakon.rada.gov.ua/laws/show/995_004\#Text) (data zvernennia: 14.01.2021) [in Ukrainian].

13. Dokument Kopenhahenskoho soveshchanyia Konferentsyy po chelovecheskomu yzmerenyiu SBSE. Kopenhahen, 29 yiunia $1990 \mathrm{~h}$. [Document of the Copenhagen Meeting of the Conference on the Human Dimension of the CSCE]. URL: https://zakon.rada.gov.ua/laws/show/994_082\#Text) (data zvernennia: 15.01.2021) [in Russian].

14. Rishennia Konstytutsiinoho sudu Ukrainy u spravi za konstytutsiinym podanniam Ministerstva vnutrishnikh sprav Ukrainy. m. Kyiv, 19 kvitnia 2001 roku, sprava № 1-30/2001 [Decision of the Constitutional Court of Ukraine in a case on a constitutional petition of the Ministry of Internal Affairs of Ukraine]. URL: https://zakon.rada.gov.ua/laws/show/v004p710-01\#Text (дата звернення: 14.01.2021) [in Ukrainian]. 
15. Public Order Act. URL: https://www.riksdagen.se/sv/dokument-lagar/dokument/svenskforfattningssamling/ordningslag-19931617 sfs-1993-1617 (data zvernennia: 15.01.2021).

16. Apply for a permit for a public gathering. URL: https://polisen.se/en/services-and-permits/permitsand-licences/permit-for-a-public-gathering/ (data zvernennia: 14.01.2021).

\author{
Ulianov Oleksiy, \\ PhD in Law, Associate Professor, \\ Honored Worker of Science and Technology of Ukraine \\ (Odessa State University of Internal Affairs, Odessa) \\ ORCID: https://orcid.org/0000-0002-3397-0965 \\ Nikolayev Oleksandr, \\ PhD in Political Sciences, Associate Professor \\ (Odessa State University of Internal Affairs, Odessa) \\ ORCID:https://orcid.org/0000-0003-4752-0110 \\ Bakhchevan Yevhen, \\ Senior Lecturer \\ (Odessa State University of Internal Affairs, Odessa) \\ ORCID:https://orcid.org/0000-0002-1459-9574
}

\title{
INTRODUCTION OF THE SCANDINAVIAN MODEL OF PUBLIC SAFETY AND ORDER DURING MASS EVENTS IN THE ACTIVITIES OF THE NATIONAL POLICE OF UKRAINE
}

The article reveals the features and advantages of the Scandinavian model of public order and security during mass events. One of the key elements of the new concept of public order protection is the introduction of "dialogue police». There are four points of view of this approach - first, get as much knowledge as possible about the composition of any crowd, second, learn to distinguish between different parts of the crowd and identify the possible risks, third, constant dialogue and communication with event organizers and crowd members and finally, assistance. The concept of public order is revealed. The legal basis for holding mass events in Ukraine is analyzed. It is established that the lack of a special law on holding mass events is one of the problems of realization of the Scandinavian model. According to the Article 39 of the Constitution of Ukraine, citizens have the right to assemble peacefully, without weapons and to hold meetings, rallies, marches and demonstrations, the holding of which is notified in advance to the executive authorities or local governments. Restrictions on the exercise of this right may be imposed by a court in accordance with the law and only in the interests of national security and public order - in order to prevent riots or crimes, to protect public health or to protect the rights and freedoms of others. According to the Decision of the Constitutional Court of Ukraine, relations in the field of holding mass events can only be regulated by law. To implement the basic principle of the "dialogue policing", which provides communication between the police and the organizers of mass events, it is important to establish a clear procedure for notification of such events. The necessity of adopting a special law on public events in Ukraine, as well as determining the procedure for notification of public events that must be submitted to the national police, has been substantiated.

Key words: police; public order; Scandinavian model; mass events; dialogue police.

Надійшла до редколегії 09.02.2021 